\title{
An unexpected allergic reaction with Saccharomyces boulardii: a case report
}

\author{
Ozgur Kartal ${ }^{1 *}$, Fevzi Demirel', Abdullah Baysan', Mustafa Gulec', Sait Yesillik', Metin Uyanýk², Ugur Musabak', \\ Osman Sener ${ }^{1}$
}

From 6th Drug Hypersensitivity Meeting (DHM 6)

Bern, Switzerland. 9-12 April 2014

\section{Introduction}

Saccharomyces boulardii (S.boulardii), known as a nonpathogenic yeast probiotic shows it's efficacy in inflammatory and infectious diseases of the gastrointestinal tract safely. This report presents an allergic reaction and positive skin test in a patient who takes S.boulardii as an antidiarrheal therapy.

\section{Case Report}

A sixty-year old male patient was admitted to the hospital with itchy rash on both ankles within 1.5 hours after ingesting S.boulardii $250 \mathrm{mg}$ capsule and nifuroxazide $100 \mathrm{mg}$ capsule. Hyperemic macular lesions surrounding the ankles were seen on physical examination. Oral antihistamine, oral and topical steroid therapies were initiated. Skin tests with suspected drugs were performed a month later. The prick and intradermal tests were performed with S.boulardii and nifuroxazide. The intradermal test with S.boulardii was detected positive at $1 / 10 \mathrm{~W} / \mathrm{vol}$ concentration. However, skin tests were found to be negative with nifuroxazide.

\section{Conclusion}

Although S.boulardii is known a safe drug in the treatment of some gastrointestinal disorders, it can not be referred completely reliable on the basis of allergic reactions. Previously, only one allergic reaction was reported effecting gastrointesinal system. Our case is important in clinical practice, because the first skin manifestation of S.boulardii allergy was presented and confirmed by skin test.

\begin{abstract}
Authors' details
${ }^{1}$ Gulhane Military Medical Academy and Medical School, Division of Immunology and Allergic Diseases, Turkey. ${ }^{2}$ Gulhane Military Medical Academy and Medical School, Department of Clinical Chemistry, Turkey.
\end{abstract}

Published: 18 July 2014

doi:10.1186/2045-7022-4-S3-P100

Cite this article as: Kartal et al:: An unexpected allergic reaction with Saccharomyces boulardii: a case report. Clinical and Translational Allergy 2014 4(Suppl 3):P100.

${ }^{1}$ Gulhane Military Medical Academy and Medical School, Division of Immunology and Allergic Diseases, Turkey

Full list of author information is available at the end of the article

Submit your next manuscript to BioMed Central and take full advantage of:

- Convenient online submission

- Thorough peer review

- No space constraints or color figure charges

- Immediate publication on acceptance

- Inclusion in PubMed, CAS, Scopus and Google Scholar

- Research which is freely available for redistribution
() Biomed Central
C Biomed Central

(c) 2014 Kartal et al; licensee BioMed Central Ltd. This is an Open Access article distributed under the terms of the Creative Commons Attribution License (http://creativecommons.org/licenses/by/4.0), which permits unrestricted use, distribution, and reproduction in any medium, provided the original work is properly cited. The Creative Commons Public Domain Dedication waiver (http://creativecommons.org/publicdomain/zero/1.0/) applies to the data made available in this article, unless otherwise stated. 